\title{
OS RISCOS DAS DECISÕES: UM ESTUDO DE CASO DA TRANSPOSICÃO DO RIO SÃO FRANCISCO
}

\author{
THE RISKS OF DECISIONS: A CASE STUDY OF THE PROPOSED SÃO FRANCISCO RIVER \\ CROSSING
}

\section{LOS RIESGOS DE LAS DECISIONES: UN ESTUDIO DE CASO DE LA TRANSPOSICIÓN DEL RÍO SÃO FRANCISCO}

Silviana Lúcia Henkes

\section{RESUMO}

Ulrich Beck, em suas obras sobre a Sociedade de Risco, defende que a tomada de decisão é a fonte dos riscos. Essa pesquisa tem como objetivo geral analisar se as decisões tomadas visando transpor as águas do Rio São Francisco, sejam administrativas ou judiciais, geram riscos e, assim, comprovar ou não a premissa teórica do autor. A pesquisa estabeleceu duas hipóteses: as decisões para a aprovação do Projeto da Transposição vão gerar riscos e a execução desse projeto desconsidera preceitos do Direito Ambiental. Ainda não há sentença judicial final, mas o percurso percorrido é exemplificativo para concluir: a) a decisão jurídica final ratificará a liminar do STF; b) a execução do projeto causará riscos desconsiderados ou subdimensionados pelo RIMA; c) os imbróglios jurídicos evidenciam a manifesta intenção política de executar esse projeto, a inaceitabilidade social da transposição, o esvaziamento da função dos comitês e que a participação pública não foi efetiva; d) o Direito Ambiental brasileiro está munido de instrumentos aptos a gerenciar o risco, mas a normatização não induz à efetividade. A pesquisa comprovou as hipóteses. Adotou-se o método indutivo.

PALAVRAS-CHAVE: Transposição do rio São Francisco. Direito Ambiental. Tomada de Decisão. Riscos.

\begin{abstract}
Ulrich Beck, in his works on the Risk Society, defends the idea that decision-making is a source of risk. This research analyzes whether the decisions made for crossing the waters of the São Francisco river, be they administrative or judicial, generate risks and thus prove or disprove Ulrich Beck's theoretical premise. The research established two hypothesis: that the decisions to approve the project will generate risks, and that the execution of this project disregards precepts of Environmental Law. There is still no final judicial sentence, but the course taken is exemplified, to conclude that: a) the final legal decision will ratify the preliminary injunctions of the Brazilian Supreme Federal Court; b) the execution of the project will cause risks that are disregarded or played down by the RIMA; c) the legal embroilments demonstrate a clear political intention to implement the project, as well as the social unacceptability of the project; the divestment of the function of the committees, and the fact that public participation is not effective; d) Environmental Law Brazilian is equipped with instruments that are capable of managing the risk, but the legislation does not favor their effectiveness. We adopted the inductive method in this research.
\end{abstract}

KEYWORDS: Transposition of the São Francisco River. Environmental Law. Decision- Making. Risks.

1 Doutora em Direito pela Universidade Federal de Santa Catarina com estágio de doutoramento na Université Paris. Professora Adjunta da Universidade Federal de Pelotas, Pelotas, Rio Grande do Sul, Brasil. Membro do Comitê Institucional para Bolsas de Iniciação Científica FAPERGS e CNPQ. Endereço para correspondência: silvi_henkes@hotmail.com 
Ulrich Beck, en sus obras sobre la Sociedad del Riesgo, postula que la toma de decisión es la fuente de los riesgos. Esta investigación tiene como objetivo general analizar si las decisiones tomadas con el objetivo de transponer las aguas del río São Francisco, ya sean administrativas o judiciales, generan riesgos y, así, comprobar o no la premisa teórica del autor. La investigación estableció dos hipótesis: las decisiones para la aprobación del Proyecto de la Transposición van a generar riesgos y la ejecución de ese proyecto desconsidera preceptos del Derecho Ambiental. Todavía no hay sentencia judicial final, pero el trayecto recorrido es ejemplificador para concluir: a) la decisión jurídica final ratificará la medida cautelar del STF; b) la ejecución del proyecto causará riesgos desconsiderados o subdimensionados por el RIMA; c) los embrollos jurídicos evidencian la manifiesta intención política de ejecutar ese proyecto, la inaceptabilidad social de la transposición, el vaciamiento de la función de los comités y que la participación pública no fue efectiva; d) el Derecho Ambiental brasileño está provisto de instrumentos aptos a gerenciar el riesgo, pero la normatización no induce a la efectividad. La investigación comprobó las hipótesis. Se adoptó el método inductivo.

PALABRAS CLAVE: Transposición del río São Francisco. Derecho Ambiental. Toma de Decisión. Riesgos.

\section{INTRODUÇÃO}

A análise da Sociedade Contemporânea a partir da percepção do risco ganhou fôlego nas últimas décadas. Pode-se afirmar que a Teoria da Sociedade de Risco está em evidência desde o lançamento da obra "A Sociedade de Risco. Para uma nova modernidade", em 1986, do professor alemão Ulrich $B^{B e c k^{2}}$. Esta obra e as demais do autor ${ }^{3}$ são as principais referências no estudo dessa temática.

Beck inovou o estudo da Teoria Social Contemporânea ao centralizar seus estudos e análises no risco e a partir dele estabelecer características, limites, desafios e transformações da Sociedade Contemporânea. Enfatiza-se que o autor não desenvolve sua teoria sobre a crise ou os problemas ambientais, pois para ele os riscos são globais, intergeracionais e atingem a sociedade como um todo.

Segundo Beck ${ }^{4}$, a decisão é a fonte dos riscos, ainda que tomada para gerir os já existentes ou para impedir sua geração. Seguindo essa linha de pensamento, este trabalho tem como objetivo geral analisar as decisões tomadas visando transpor as águas do Rio São Francisco, isto é, a decisão do Conselho Nacional de Recursos Hídricos, aprovando a transposição (em 17/01/2005); a decisão da Agência Nacional de Águas, concedendo a Outorga Hídrica n. 411 (em 22/09/2005); a decisão do IBAMA, concedendo ao Ministério da Integração Nacional a Licença Ambiental Prévia Retificatória (em 29/12/2006) e também a Licença Ambiental de Instalação n. 438/2007 (em 23/03/2007); a decisão liminar do Ministro Sepúlveda Pertence, viabilizando a continuidade da execução do Projeto (em 18/12/2006) e a do Plenário do Supremo Tribunal Federal, que por 6 votos contra 3 manteve a liminar (dia 19/12/2007), no intuito de comprovar a premissa teórica de Beck, qual seja, se realmente as decisões estão gerando riscos, sem resolver as causas que the deram origem.

O trabalho tem, como objetivos específicos, apresentar uma breve contextualização histórica da transposição e também do projeto em execução; analisar se as decisões favoráveis à transposição, além de gerarem riscos, desrespeitam o Direito Ambiental. A pesquisa estabelece duas hipóteses, a saber: se as decisões, sejam as tomadas no âmbito da administração pública ou do judiciário, vão gerar riscos; e se a execução do Projeto de Transposição desconsidera preceitos do Direito Ambiental brasileiro. Adotou-se, para a realização do trabalho, o método indutivo.

2 BECK, Ulrich. La sociedade del riesgo. Hacia uma nueva modernidad. Barcelona: Paidos, 1986, $304 p$.

3 BECK, Ulrich. La sociedad del riesgo global. Madrid: Siglo Veintiuno de España Editores, 1999, $290 p$.

4 BECK, Ulrich. La sociedad del riesgo global. p.18-19. 
Justifica-se a realização deste estudo, em virtude do contexto emblemático da aprovação do projeto, marcado por intensas manifestações populares e de classes associativas contrárias à decisão e também pelos inúmeros imbróglios jurídicos decorrentes do truncado licenciamento ambiental. As análises desta pesquisa auxiliam na reflexão para as futuras decisões e para demonstrar que a normativização ambiental não significa a aplicabilidade e a efetividade das normas.

\section{O CONTEXTO HISTÓRICO DA TRANSPOSIÇÃO DO RIO SÃO FRANCISCO}

Desde o século XIX, a Transposição do rio São Francisco tem sido defendida como a solução para "os problemas do Nordeste". A primeira proposta, ainda muito vaga, foi idealizada em 1818, pelo ouvidor José Raimundo dos Passos Barbosa, a qual tratava da abertura de um canal que levaria água do rio São Francisco ao rio Jaguaribe ${ }^{5}$.

Pouco tempo depois, Dom Pedro II também começou a defender a transposição como o meio mais eficaz para combater os problemas da seca no Nordeste. Então o Projeto de Transposição do rio São Francisco começou a ser delineado. Por volta de 1850, o engenheiro Henrique Fernando Halfed foi encarregado pelo Governo Imperial de fazer um estudo sobre o rio. O resultado foi publicado no "Atlas de Relatório Concernente à Exploração do rio São Francisco desde a Cachoeira da Pirapora até ao Oceano Atlântico"6, publicado em 1860. Neste estudo, Halfeld defendeu a ideia de transpor as águas do rio São Francisco para o rio Jaguaribe e identificou o ponto para a retirada das águas em Cabrobó $(P E)^{7}$.

As ideias de Dom Pedro II foram esquecidas até que, em 1912, com a criação da Inspetoria Federal de Obras contra a Seca (IOCS), o projeto voltou à pauta, sendo descartado, em 1920, como inviável, pois, à época, não se tinha tecnologia para superar as barreiras do relevo superiores a 200 metros. Quase um século depois da publicação do relatório de Halfeld, o Presidente Juscelino criou a Superintendência do Desenvolvimento do Nordeste (SUDENE), confiada ao Ministro Celso Furtado, que não defendia abertamente a transposição por temer os riscos da salinização do solo nas áreas irrigadas. Assim, o projeto foi novamente arquivado8.

No Governo de Figueiredo (1979-1985), o Ministro do Interior, Mário Andreazza, resgatou o projeto em 1980, e seus planos fluíram até 1984, quando uma grande mortandade de peixes no rio São Francisco fez com que esse plano fosse engavetado?.

No Governo Itamar (1992-1995), os Ministros da Integração Regional, Aluízio Alves e do Planejamento, Beni Veras, resgataram-no novamente em 1994. Nesse governo, foi dado início ao licenciamento ambiental e formulado o Termo de Referência para o EIA/RIMA, em 10/05/1994. Na época, pensava-se em retirar $7,5 \%$ da vazão do rio para a obra, contra os $1,5 \%$ do atual projeto ${ }^{10}$.

No pleito eleitoral para a presidência da República (1994), o candidato Fernando Henrique Cardoso não se manifestava diretamente sobre a transposição. Contudo, depois de eleito (1996), destinou R\$ 500 milhões para a retomada do projeto ${ }^{11}$. Em junho de 1996, o Ministério do Planejamento e Orçamento requereu a concessão da licença prévia para o empreendimento (licenciamento iniciado no Governo Itamar) ${ }^{12}$.

Em 1998, ano eleitoral, o candidato à reeleição, FHC, já era um grande defensor da transposição, numa versão mais racional, com vazões muito menores que as propostas anteriores. Esse

5 VILLA, Marco Antônio. Um projeto de quase 2 séculos. Estado de São Paulo, São Paulo, 04 p. 01. fev. 2004.

6 VILLA, Marco Antônio. Um projeto de quase 2 séculos.p.01.

7 LEITE, Marcelo. Política serve projetos de tempos em tempos. Folha de São Paulo, São Paulo, p. especial 07, 09 out. 2005.

8 LEITE, Marcelo. Política serve projetos de tempos em tempos. p. especial 07.

9 LEITE, Marcelo. Política serve projetos de tempos em tempos. p. especial 07.

10 VILLA, Marco Antônio. Um projeto de quase dois séculos. p. 01; LEITE, Marcelo. Política serve projetos de tempos em tempos. p. especial 07; BAHIA, Carolina Medeiros. O Projeto da Integração do rio São Francisco às bacias do Nordeste Setentrional e a Lei 9433/1997. 2006, p.01.

11 LEITE, Marcelo. Política serve projetos de tempos em tempos. p. especial 07.

12 BAHIA, Carolina Medeiros. O Projeto da Integração do rio São Francisco às bacias do Nordeste Setentrional e a Lei 9433/1997. p. 01 
empreendimento, tornou-se um dos pontos de destaque do plano desenvolvimentista "Avança Brasil", proposto por FHC na busca da reeleição ${ }^{13}$.

Em 11/01/2000, o pedido de licença ambiental prévia foi renovado pelo Ministério da Integração Nacional, que protocolou o EIA/RIMA em 03/07/2000. Após a realização de algumas adequações no EIA/RIMA, determinadas pelo IBAMA, e a disponibilização do seu conteúdo ao público, foram definidas as datas para a realização das audiências públicas Contudo, em decorrência das falhas detectadas no EIA/RIMA e da necessidade de complementação dos estudos de impacto ambiental, o Ministério Público e diversas associações propuseram ações judiciais ${ }^{14}$.

Encerrados os mandatos de FHC (1995-2002), as obras não tinham saído do papel, em decorrência do embargo judicial e também da grave crise energética (apagão) ocorrida no Brasil em 2001. Então, o projeto foi arquivado no mesmo ano ${ }^{15}$.

No pleito eleitoral para a Presidência da República (2002), o então candidato Luís Inácio Lula da Silva não defendia abertamente a transposição. Contudo, após eleito, em seu primeiro mandato (2003-2006), tornou-se um defensor do projeto e o elegeu como uma das principais obras de seu governo ${ }^{16}$. O então Presidente Lula deu "carta branca" ao Ministro da Integração Nacional, Ciro Gomes, para retomar o processo de licenciamento paralisado, e o Governo apresentou um novo estudo de impacto ambiental ao IBAMA, em 12/07/2004. Inúmeras ações judiciais foram propostas por órgãos ambientais, experts e membros da sociedade para contestar os resultados apresentados.

Depois de várias tentativas, no primeiro mandato do Governo Lula (2003-2006), as obras foram inicializadas e continuam no Governo Dilma, apesar das inúmeras contestações judiciais e sociais. Ainda não há decisão jurídica transitada em julgado (janeiro 2013), contudo a execução do projeto continua amparada na liminar concedida pelo Ministro do STF, Sepúlveda Pertence em 18/12/2006 ratificada pelo Plenário do STF (em 19/12/2007). As obras de alguns trechos foram paralisadas temporariamente devido ao rompimento de contratos e à necessidade de novas licitações, atrasando o cronograma inicial de entrega das obras.

Salienta-se que a execução do Projeto de Transposição do rio São Francisco é defendida pelo Governo Federal tanto do ex-presidente, Luís Inácio Lula da Silva, quanto da presidenta Dilma Roussef, como a solução para os problemas da seca e como promessa de desenvolvimento do Semiarido do Nordeste brasileiro.

\section{O PROJETO DE TRANSPOSIÇÃO DO RIO SÃO FRANCISCO}

O Projeto de Transposição idealizado pelo Governo Lula e atualmente executado pelo Governo Dilma tem como objetivo captar água em dois pontos do rio São Francisco e levá-la ao Semiárido para prover água às populações; assegurar safras agrícolas, atividades industriais e o turismo; fixar a população rural na região; promover o crescimento das atividades produtivas; diminuir os gastos públicos com medidas emergenciais durante as secas; garantir água para uma infraestrutura de reserva e de distribuição já existentes (açudes, rios e adutoras); enfim, segundo o Governo, promover o desenvolvimento da região ${ }^{17}$.

A distribuição da água se dará através de dois eixos. O Eixo Norte (Latitude Sul $08^{\circ} 32^{\prime} 41,1^{\prime \prime}$ e Longitude Oeste $39^{\circ} 27^{\prime} 15,2^{\prime \prime}$ ) visa atingir Pernambuco (PE), Ceará (CE), Paraíba (PB) e Rio Grande do Norte (RN). O Eixo Leste (Latitude Sul $08^{\circ} 49^{\prime} 37,7^{\prime \prime}$ e Longitude Oeste $38^{\circ} 24^{\prime} 43,3^{\prime \prime}$ ) beneficiará parte do Sertão e as regiões agrestes de Pernambuco e da Paraíba.

13 LEITE, Marcelo. Política serve projetos de tempos em tempos. p. especial 07.

14 HENKES, Silviana L. As decisões político-jurídicas frente à crise hídrica e aos riscos: lições e contradições da Transposição do Rio São Francisco. Tese (Doutorado em Direito). Curso de PósGraduação em Direito. Universidade Federal de Santa Catarina. Florianópolis. 2008.

15 CAUBET, Christian Guy; ARAÚJO, José Theodomiro de. Le transfert des eaux du fleuve. São Francisco. Paris. Écologie \& Politique, n.29, p. 168, 2004.

16 COELHO, Marco Antônio Tavares. A transamazônica de Lula. Correio Braziliense, Brasília, 27 set. 2004.

17 MINISTÉRIO DA INTEGRAÇÃO NACIONAL. Relatório de Impacto Ambiental da Transposição, Brasília, p. 02,03,08. jul. 2004. 
Juntos, os dois eixos terão capacidade máxima de $127 \mathrm{~m}^{3} / \mathrm{s}$ (99 no Eixo Norte e 28 no Leste). ${ }^{18}$ A vazão prevista no projeto para 2013 era de $26,4 \mathrm{~m}^{3} / \mathrm{s}\left(16,4 \mathrm{~m}^{3} / \mathrm{s}\right.$ no Eixo Norte e $10 \mathrm{~m}^{3} / \mathrm{s}$ no Leste), correspondente a $1,5 \%$ da vazão mínima do rio e para 2025 , de $63,5 \mathrm{~m}^{3} / \mathrm{s}\left(42,4 \mathrm{~m}^{3} / \mathrm{s}\right.$ no Eixo Norte e $21,1 \mathrm{~m}^{3} / \mathrm{s}$ no Eixo Leste) $)^{19}$. Devido à paralisação de alguns trechos das obras, a vazão prevista para 2013 será utilizada somente em 2015, data que o Governo Federal estima para a entrega da primeira parte das obras ${ }^{20}$.

Após a repercussão na mídia acerca do estado de deterioração das obras da transposição, em virtude da paralisação da execução de sete dos dezenove trechos, e também da suspeita de irregularidades nos contratos de obras e serviços em cinco trechos, o Governo Federal noticiou que as medidas judiciais já tinham sido tomadas e que as obras serão totalmente retomadas até maio de 2013, após a conclusão de novas licitações para saldos remanescentes ${ }^{21}$. Cabe ressaltar que, desde o início do licenciamento ambiental, diversas irregularidades foram constatadas pelo Tribunal de Contas da União nos contratos e nas licitações da transposição 22 . O TCU recomendou ao Governo Federal suspender os pagamentos até a decisão judicial final sobre o projeto. O valor da obra, estimado inicialmente em $\mathrm{R} \$ 4$ bilhões, foi atualizado para $\mathrm{R} \$ 8$ bilhões (este valor representa 0 custo da construção dos canais de concreto, estações de bombeamento e reservatórios) ${ }^{23}$; contudo ainda devem ser contabilizados os gastos relativos à manutenção e à operacionalização do sistema, estimados em R\$127 milhões que ficarão a cargo dos Estados "beneficiados" (CE, PE PB, RN) ${ }^{24}$.

\section{A OPOSIÇÃO AO PROJETO DE TRANSPOSIÇÃO DO RIO SÃO FRANCISCO}

Foram inúmeras ações judiciais propostas por associações e entidades ambientais para impedir a execução do Projeto de Transposição do rio São Francisco, tanto pelas falhas apresentadas no EIA/RIMA, quanto pela condução truncada do licenciamento e, em especial, pela inaceitabilidade da obra, em virtude dos riscos.

Os entraves jurídicos iniciaram com a retomada do processo de licenciamento ambiental por meio da apresentação do novo EIA/RIMA (12/07/2004) ${ }^{25}$. Diversas entidades ambientalistas impetraram ações contra atos do IBAMA (concessão da licença), da ANA (concessão da outorga hídrica) e do Ministério da Integração Nacional (planejamento e execução do projeto de transposição).

Ainda com as ações judiciais em trâmite, foi anunciada, em regime de urgência, uma reunião do Conselho Nacional de Recursos Hídricos (CNRH) para o dia 30/11/2004, o que tornaria possível deliberar sobre o projeto somente nesta reunião. O lapso temporal entre a divulgação da reunião e a sua realização era exíguo e a matéria ainda não tinha sido objeto de análise pelas Câmaras Técnicas do Conselho. Tal conjuntura evidenciava o cunho político da decisão a ser tomada ${ }^{26}$. O CNRH defendia sua competência para deliberar sobre o projeto, amparado pela Lei 9.433/97, artigo 35, inciso III.

18 MINISTÉRIO DA INTEGRAÇÃO NACIONAL. Relatório de Impacto Ambiental da Transposição. p. 23.

19 MINISTÉRIO DA INTEGRAÇÃO NACIONAL. Relatório de Impacto Ambiental da Transposição. p. 23.

20 MINISTÉRIO DA INTEGRAÇÃO NACIONAL. Site oficial do Ministério da Integração Nacional. Contém informações, projetos e ações executadas. Disponível em: <http://www.integracao.gov.br>. Acesso em: janeiro-março 2013.

21 MINISTÉRIO DA INTEGRAÇÃO NACIONAL. Site oficial do Ministério da Integração Nacional. Acesso em: janeiro-março 2013.

22 TRIBUNAL DE CONTAS DA UNIÃO. Acórdão 2017/2006, de 03 nov.2006, publicado no D.O.U. 06 nov. 2006. Disponível em: http://www.cbhsao francisco.org.br. Acesso em: nov. 2006.

23 MINISTÉRIO DA INTEGRAÇÃO NACIONAL. Relatório de Impacto Ambiental da Transposição. p.38.

24 SALOMON, Marta. Obra do São Francisco consome 12 bilhões e ainda gera discussão. Nem greve de fome do bispo faz o governo cessar a liberação de recursos para o Projeto de Transposição. Folha de São Paulo, São Paulo, p. especial 03, 09 out.2005; AB'SÁBER, Aziz Nacib. Sobre a Transposição do São Francisco. As águas do rio não são a panacéia para os problemas do Semi-Árido. Scientific American Brasil, São Paulo, ano 3, n. 35, p.A18, abr. 2005.

25 HENKES, Silviana L. As decisões político-jurídicas frente à crise hídrica e aos riscos: lições e contradições da Transposição do Rio São Francisco. p.315.

26 BAHIA, Carolina Medeiros. O Projeto da Integração do rio São Francisco às bacias do Nordeste Setentrional e a Lei 9433/1997. p. 02-03. 
Também foi divulgada a realização de audiências públicas, a partir de 06/12/2004, com o objetivo de apresentar o EIA/RIMA à sociedade. Diante desses fatos, novas ações judiciais foram propostas no intuito de impedir a deliberação do CNRH sobre o projeto. Também em face dessas irregularidades (agendamento de audiências e da reunião do CNRH), o Ministério Público Federal e o Ministério Público do Distrito Federal impetraram, em novembro de 2004, um mandado de segurança preventivo contra o ato da presidência do $\mathrm{CNRH}$, requerendo em liminar a suspensão das reuniões e, portanto, da deliberação de tal projeto.

No dia 06/12/2004, o juiz da $14^{a}$ Vara Federal de Salvador determinou a suspensão das audiências públicas e do licenciamento ambiental e de qualquer procedimento de contratação por meio de licitação ou qualquer outro meio que objetivasse a implantação do projeto. Em decorrência do embargo judicial, as audiências públicas não foram realizadas. Também em 06/12/2004, o juiz da $3^{a}$ Vara Federal de Sergipe ordenou: a) suspensão imediata do processo de licenciamento ambiental; b) abstenção da ANA de expedir a outorga do direito de uso das águas do São Francisco; c) imposição ao Ministério da Integração Nacional e à União Federal da obrigação de não fazer (licitar), declarando nula a existente ${ }^{27}$.

Todavia nova decisão judicial suspendeu as decisões anteriores e uma nova rodada de audiências públicas com início em curto espaço de tempo foi divulgada pelo IBAMA ${ }^{28}$. No início de janeiro de 2005, o CNRH designou nova reunião para 17/01/2005, cuja pauta era a deliberação sobre o projeto ${ }^{29}$.

Entidades e órgãos de defesa do meio ambiente e dos interesses difusos e coletivos ingressaram com novas ações em 05/01/2005, contra o IBAMA, a União e a ANA, apontando a ilegalidade do projeto, assim como as diversas irregularidades presentes no EIA/RIMA. Postularam, liminarmente, a invalidação das audiências designadas; a suspensão do procedimento de licenciamento ambiental e impedir a União de praticar qualquer ato visando concretizar o Projeto de Integração da Bacia do São Francisco ${ }^{30}$.

Contudo as liminares foram negadas e o CNRH aprovou o Projeto de transposição na reunião ocorrida dia 17/01/2005 e iniciou a rodada de audiências públicas programadas.

Por meio da Reclamação 3074, processada no Supremo Tribunal Federal (STF), admitiu-se o ingresso da União no polo passivo, e a competência originária do STF em todos os processos em que litigam Estados-membros ou órgãos seus contra a União ou autarquia federal acerca do Projeto da Transposição. Por consequência, todas as ações em trâmite, tendo como objeto o projeto ou seu licenciamento, foram remetidas ao STF.

Mesmo com as ações em trâmite, sem decisão transitada em julgado, o IBAMA concedeu a Licença Ambiental Prévia no. 200/2005, em 29/05/2005 ao Ministério da Integração Nacional. Em 18/12/2006, o Ministro Sepúlveda Pertence (STF) concedeu liminar, a fim de possibilitar o andamento do licenciamento ambiental. Assim, todas as decisões que suspendiam o licenciamento ambiental ou qualquer outro ato referente à transposição foram cassadas. A liminar foi referendada pelo Plenário do STF, 6 votos contra 3, em 19/12/2007.

A partir da liminar, o Ministério da Integração Nacional deu continuidade ao pedido de licenciamento e a Licença Prévia Retificatória foi concedida em 29/12/2006 e a Licença de Instalação em 23/03/200731. Alguns processos avocados pelo STF seguem tramitando (parâmetro janeiro 2013): ACO 820; ACO 876; ACO 857; ACO 858; ACO 872; ACO 873; ACO 870; ACO 886 32 . Alguns foram extintos por ilegitimidade processual das partes: ACO 871; AC 981; ACO $869^{33}$.

27 BAHIA, Carolina Medeiros. O Projeto da Integração do rio São Francisco às bacias do Nordeste Setentrional e a Lei 9433/1997. p. 02-03.

28 BONI, Ana Paula. Governo quer levar água para 12 milhões de pessoas. Folha de São Paulo, São Paulo, p. especial 04, 09 out. 2005.

29 BAHIA, Carolina Medeiros. O Projeto da Integração do rio São Francisco às bacias do Nordeste Setentrional e a Lei 9433/1997. p. 03-04; ALENCAR, 2005, p.06

30 BAHIA, Carolina Medeiros. O Projeto da Integração do rio São Francisco às bacias do Nordeste Setentrional e a Lei 9433/1997. p.04-05.

31 BRASIL. Supremo Tribunal Federal. Ação Cível Originária 876. Autores: Entidades Integrantes do Fórum de Defesa Permanente do São Francisco. Rés: União e IBAMA. Brasília. Relator Min. Sepúlveda Pertence. p.46-50. Brasília, 18 dez. 2006. Disponível em: 〈http://www.stf.gov.br〉. Acesso em: out.2007.

32 BRASIL. Supremo Tribunal Federal. Ação Cível Originária 876. p. 18-23.

33 BRASIL. Supremo Tribunal Federal. Ação Cível Originária 876. p. 18-23. 
Na decisão liminar, o Ministro Sepúlveda Pertence, em síntese, elenca os argumentos utilizados nas ações judiciais propostas contra a transposição (interromper o licenciamento ambiental, cassar a licença ambiental prévia 200/2005 e impedir a execução das obras) ${ }^{34}$ :

a) existirem falhas e omissões relevantes no EIA/RIMA, principalmente por não ter considerado os impactos ambientais, sociais e econômicos à parte mineira e a baiana da bacia;

b) não terem sido contempladas todas as alternativas tecnológicas e de localização do projeto, conforme prescrito no artigo $5^{\circ}$, da Res. CONAMA 01/86;

c) desconsiderar a Região do Alto e Médio São Francisco na área de influência direta do empreendimento;

d) haver imprecisões técnicas quanto aos recursos hídricos da bacia, aproveitamento hidrelétrico e propostas de sistemas hidrossanitários;

e) não ter sido cumprida a exigência de acompanhamento da certidão dos municípios atingidos pelo projeto;

f) faltar a autorização do Congresso Nacional para a realização do projeto, pois há aproveitamento de recursos hídricos em terras indígenas, de acordo com o artigo $231, \S 3^{\circ}$, da CF/88;

g) desconsiderar o Plano Decenal da Bacia (2004-2013);

h) desrespeitar a Política Nacional de Recursos Hídricos (Lei 9433/97);

i) inviabilizar a realização das audiências públicas ante o curto lapso entre a designação e a sua realização, além da distância considerável dos locais das pessoas diretamente interessadas;

j) haver vícios na aprovação da Resolução 411, emitida pela ANA, ante a ausência da manifestação da Câmara Técnica;

I) conceder a licença ambiental prévia 200/2005, apesar das falhas e das omissões apresentadas pelo EIA/RIMA, sem oportunizar a efetiva participação popular.

O IBAMA, o Ministério da Integração Nacional e a União, segundo o Ministro Sepúlveda Pertence, em apertada síntese, alegam ${ }^{35}$ :

a) o cumprimento das determinações legais;

b) a realização das audiências públicas e a concessão da licença ambiental prévia não significam a conclusão do licenciamento, tampouco o início das obras; portanto, outros esclarecimentos, bem como eventuais necessárias complementações do EIA/RIMA, poderiam decorrer das indagações colhidas nas audiências;

c) a concessão da licença prévia não provoca nenhum dano ao ambiente, pois não foram iniciadas as obras físicas do projeto;

d) quanto às irregularidades nas licitações e nas contratações para a execução das obras, à época, aduziu a União que o Ministério da Integração Nacional tão somente divulgou o primeiro edital com o intuito de contratar empresa especializada para prestar apoio técnico ao Ministério da Integração, visando à obtenção das licenças ambientais;

e) a ilegitimidade ativa de algumas das entidades autoras.

No julgamento da liminar, o Ministro ressaltou que a solução das controvérsias versa sobre o questionamento: a concessão da licença prévia (in)depende da aprovação do EIA/RIMA. Se necessária, todas as discussões sobre os estudos devem estar encerradas antes de ser deferida a licença prévia.

O Ministro Sepúlveda Pertence considerou que, para a concessão da licença prévia, basta que os estudos requisitados pelo IBAMA sejam satisfatórios, principalmente no pertinente à viabilidade

34 BRASIL. Supremo Tribunal Federal. Ação Cível Originária 876. p.14-16.

35 BRASIL. Supremo Tribunal Federal. Ação Cível Originária 876. p.16. 
ambiental do projeto, à sua localização e à sua concepção. Segundo o Ministro, os demais estudos somente são necessários para obter a licença de instalação e de operação, pois, antes, não são realizadas obras físicas.

O Ministro considerou também ter o EIA/RIMA cumprido, pelo menos sob o prisma formal, com todas as exigências legais, em especial, quanto aos requisitos prescritos pela Resolução CONAMA 01/86, em seu artigo $5^{\circ}$. E mencionou que "os vícios e as falhas acaso detectados no seu conteúdo poderão e deverão ser corrigidos no decorrer do processo de licenciamento ambiental, certo que sua eventual existência não significa, necessariamente, frustração do princípio da participação pública" ${ }^{36}$.

Concluiu ainda que, para o IBAMA, os alegados vícios de conteúdo do EIA/RIMA não foram suficientes para impedir a concessão da Licença Prévia 200/2005. Quanto à inexistência das certidões das prefeituras municipais, o magistrado entendeu serem necessárias para o licenciamento ambiental e não especificadamente no momento da apresentação do EIA/RIMA e, como foram apresentadas posteriormente, mas em tempo, considerou sanada a irregularidade. Compreendeu ter o IBAMA cumprido a legislação e os prazos legalmente prescritos quando designou as audiências públicas e que o cancelamento delas não impede a concessão da licença prévia. Isso "implicaria a punição do empreendedor, quando é certo que não se the pode imputar culpa pelos fatos" ${ }^{\prime 37}$.

Quanto à suposta ilegalidade da outorga de direito do uso das águas e do certificado de avaliação da sustentabilidade hídrica emitidas pela ANA, o Ministro considerou serem conclusivos os argumentos apresentados pela ANA.

Com base nesses argumentos e fatos, o Ministro Sepúlveda Pertence cassou em 18/12/2006 todas as liminares que suspendiam o processo de licenciamento ambiental, em específico a licença prévia concedida pelo IBAMA. A partir desta decisão liminar, o Ministério da Integração Nacional deu continuidade ao pedido de licenciamento e a Licença Prévia Retificatória foi concedida em 29/12/2006 e a Licença de Instalação em 23/03/200738.

Convém ainda destacar que, na véspera da concessão da Licença de Instalação 438/2007, o Procurador do Ministério Público Federal do Distrito Federal, Francisco Guilherme Vollstedt Bastos, recomendou ao presidente do IBAMA não expedir a referida licença até que os projetos executivos fossem concluídos e as audiências públicas (para debater os estudos ambientais complementares) fossem realizadas ${ }^{39}$.

Ratifica-se que, antes de ser conferida a licença de instalação, o Tribunal de Contas da União ${ }^{40}$, em 03/11//2006, recomendou ao Ministério da Integração Nacional não iniciar as obras ante a ausência de segurança jurídica e a constatação de inúmeras irregularidades.

Na verdade, a licença de instalação foi concedida sem a realização das audiências recomendadas pelo Ministro Sepúlveda Pertence. Dispensável mencionar que as audiências são necessárias para dar publicidade aos estudos do projeto os quais não tinham sido apresentados quando da concessão da licença prévia. Sem dúvida, seria a oportunidade para a sociedade participar. Com a licença de instalação em mãos, o Ministério da Integração Nacional deu início às obras da transposição.

Ante a não realização de audiências públicas, inexistência dos estudos conclusivos e da controvérsia nos estudos apresentados, o Procurador Geral da República, Antônio Fernando Souza, em fevereiro de 2007, ajuizou agravo regimental no STF, pedindo a suspensão da licença ambiental de instalação e cassação da licença prévia. Além disso, solicitou que o Congresso Nacional e as populações indígenas fossem consultadas ${ }^{41}$.

Em que pese o STF ter avocado todos os processos, no dia 10/12/2007, o Tribunal Regional

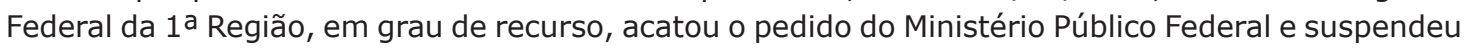

36 BRASIL. Supremo Tribunal Federal. Ação Cível Originária 876. p. 46.

37 BRASIL. Supremo Tribunal Federal. Ação Cível Originária 876. p. 29-50.

38 BRASIL. Supremo Tribunal Federal. Ação Cível Originária 876. p.46-50.

39 MINISTÉRIO PÚBLICO FEDERAL. Site oficial do Ministério Público Federal. Contém informações, projetos e ações executadas. Disponível em: <http://www.mpf.gov.brr>. Acesso em: março 2008.

40 TRIBUNAL DE CONTAS DA UNIÃO. Acórdão 2017/2006.

41 POMPEU, Carolina. Suspensa a Transposição do São Francisco. Notícias do Ministério Público Federal. Disponível em: http:// noticias.pgr.mpf.gov.br/noticias-dosite. Acesso em: 11 dez.2007. 
liminarmente as obras do Projeto de Integração do Rio São Francisco. Para o Ministério Público Federal, o projeto não poderia ter sido aprovado pelo Conselho Nacional de Recursos Hídricos pelos seguintes motivos:

a) o aporte hídrico pleiteado para a transposição era alvo de um procedimento administrativo no Comitê de Bacia Hidrográfica do rio São Francisco;

b) o projeto viola o Plano Decenal da Bacia, por visar ao aproveitamento econômico dos usos da água;

c) o projeto também desrespeita os princípios da gestão descentralizada da água e da participação popular instituído pela PNRH (Lei 9.433/97).

Cabe destacar que a Diretoria do Comitê da Bacia Hidrográfica do rio São Francisco, reunida em Brasília, no dia 03/07/2007, reiterou sua resistência à transposição e publicou a seguinte nota:

\footnotetext{
A Diretoria Colegiada do Comitê da Bacia Hidrográfica do rio São Francisco, reunida em Brasília, reitera a sua posição contrária ao Projeto de Transposição e lamenta que o Governo Federal esteja dando inicio às obras sem aguardar o exame de mérito das diversas ações que tramitam no Supremo Tribunal Federal além de atropelar o diálogo prometido pelo próprio Presidente da República e que foi interrompido pela ânsia de executar o projeto a qualquer custo, inclusive valendo-se do Exército Brasileiro para criar um fato consumado quanto ao início da transposição.
}

Em sessão plenária, no dia 19/12/2007, o STF, por seis votos contra três, revogou a liminar concedida pelo TRF e julgou improcedente o agravo ajuizado pelo Procurador-Geral da República.

Embora todas as liminares tenham sido cassadas pelo STF, até o momento (janeiro de 2013) não há uma decisão transitada em julgado. Diversos processos, por exemplo, Reclamação 3883, ACO 876, ACO 872, ACO 1052, ACO 873, ACO 820, ACO 870, ainda tramitam no STF com o escopo de obstaculizar o licenciamento e a execução das obras da Transposição.

Ainda não há decisão judicial transitada em julgado, todavia é difícil acreditar que o STF mude os rumos da transposição. Por outro lado, é incontestável a decisão política de executar o projeto a qualquer custo.

\section{QUESTIONAMENTOS ACERCA DA DESCONSIDERAÇÃO DO DIREITO AMBIENTAL}

Nos últimos anos, o Direito assumiu um papel de destaque na gestão ambiental, em especial no acautelamento de danos e riscos. Afora a criação de instrumentos acautelatórios, por exemplo, o licenciamento ambiental e a avaliação de impacto ambiental (por meio dos diversos estudos e relatórios de impacto ambiental), institutos, como o da prescrição e o da responsabilidade civil, vêm sendo reconfigurados para se amoldarem ao contexto e às exigências da sociedade contemporânea. Embora se questione, parte da doutrina já defende com entusiasmo a imprescritibilidade dos danos ambientais. Na responsabilização pelos danos ambientais, permite-se flexibilizar a prova do nexo causal, assim como se admite, ainda que de modo incipiente, a responsabilização por danos futuros e pela geração de riscos a outrem.

Além disso, não se pode olvidar que as normas devem ser aplicadas à luz dos princípios e do Direito Ambiental, em especial, dos princípios da prevenção, da precaução e da participação pública materializados no licenciamento ambiental, por meio de audiências públicas e de avaliações de impacto ambiental.

Ao analisar o cenário de idealização, aprovação e início de execução do Projeto de Transposição do rio São Francisco, surge o questionamento: o Direito Ambiental vigente foi (des)respeitado na tomada de decisão de transpor as águas do rio São Francisco? Para responder tal questão, torna-se indispensável analisar se foram observados os princípios acima mencionados, no sentido de impedir a geração de riscos, danos e impactos ambientais, e se foi propiciada a participação pública. Também é necessário verificar as diretrizes da Política Nacional de Recursos Hídricos e as estabelecidas do Plano Decenal da Bacia do rio São Francisco (2004-2013). 


\section{O DESRESPEITO AOS PRINCÍPIOS AMBIENTAIS E AO LICENCIAMENTO AMBIENTAL}

Os princípios da prevenção e da precaução visam ao acautelamento de impactos, danos e riscos ambientais; contudo se distinguem. O princípio da precaução determina que a ausência de certeza quanto à ocorrência de danos ambientais (risco de danos) deve apontar para a adoção de providências capazes de impedir o resultado lesivo, obstando, se necessário, o desenvolvimento da atividade potencialmente causadora do prejuízo. Enquanto o princípio da prevenção trabalha com os indicativos técnicos de iminência da produção de um dano, certo e definido, acenando a adoção de medidas preventivas, antes da consumação "anunciada" do resultado prejudicial ao meio ambiente, ou seja, é inspirado na adoção de critérios de antecipação diante de um resultado certo, mas não desejado (dano ambiental futuro).

A doutrina e a jurisprudência, esta ainda muito tímida, admitem a responsabilização por danos futuros e por geração de riscos. Tratando-se de danos futuros ou riscos de danos, a responsabilidade civil não visa à reparação e/ou à indenização dos danos, mas o impedimento de sua materialização por meio da imposição de astreintes, paralisação da atividade ou do empreendimento, até que sejam adotadas medidas acautelatórias, por exemplo.

Outra reflexão que deve ser proposta - pois indispensável à resolução da problemática deste trabalho - é acerca da participação pública no Projeto da transposição do rio São Francisco. A Política Nacional de Recursos Hídricos elege como um dos seus fundamentos (Lei 9.433, artigo $1^{\circ}$. inciso VI) a descentralização e a participação popular.

Necessário relembrar que a participação pública foi incorporada no Direito brasileiro e, em consequência, o cidadão conquistou, além de um novo espaço de ação, uma nova identidade e novos direitos: participação em audiências públicas (Resolução do CONAMA 09/87), em conselhos e comitês (Lei 9.433/97 e Resolução CNRH 14/2000); legitimidade para promover ação popular ambiental visando anular ou impedir atos lesivos ao ambiente (Lei 4.717/65); direito à informação de conteúdo ambiental existente em órgãos públicos (Lei 10.650/03) e, principalmente, o direito/ dever ao meio ambiente ecologicamente equilibrado (CF/88, artigo 225).

Embora o direito à participação esteja disciplinado no ordenamento jurídico, os cidadãos enfrentam obstáculos de ordem prática, política, jurídica e cultural na tentativa de participar, porquanto, apesar de a coletividade ter assento nos comitês gestores de recursos hídricos, esta nem sempre é paritária.

Participar não é assistir à audiência pública ou presenciá-la, tampouco ter representantes num colegiado sem que eles possam realmente influenciar a decisão. Participar é poder influenciar na decisão. Para Delnoy ${ }^{42}$, a participação consiste no conjunto de mecanismos e instrumentos que permitem à coletividade e ao particular influenciar de maneira direta, ainda que sem poder decisório, na adoção e na aplicação das decisões.

Marcondes e Andrade ${ }^{43}$ entendem que, embora os mecanismos de participação tenham aumentado nos últimos anos, ainda não fazem diferença no Brasil, contudo tenham avançado e se institucionalizado, pois é preciso que eles garantam uma parcela do poder de decisão, visto que, sem isso, não há participação de verdade. Hermitte ${ }^{44}$ enfatiza que, no âmbito da Sociedade de Risco, o cidadão não pode escapar dos efeitos da geração de riscos, enquanto não participa da decisão.

O Projeto da Transposição foi apresentado pronto à sociedade, não houve diálogo durante a sua idealização, impossibilitando o debate acerca da sua viabilidade ou da inviabilidade de projetos alternativos. Depois de pronto, para cumprir as formalidades legais, foram definidas as audiências públicas.

42 DELNOY, Michel. Définition, notion de base, raison d'être et sources juridiques des procedures de participation du public. In: JADOT, Benoît. La participation du public au processus de decision en matière d'environnement et d'urbanisme. Bruxelles: Bruylant, 2005, p.10.

43 MARCONDES, Neusa; ANDRADE, Marília Freire de. A História se repete. Como Trajédia ou como comédia. In: DOWBOR, Ladislau; TAGNIN, Rentato Arnaldo (Orgs). Administrando a água como se fosse importante. Gestão Ambiental e sustentabilidade. São Paulo: Senac, 2005, p. 87.

44 HERMITTE, Marie-Angèle. Os fundamentos jurídicos da sociedade do risco. Uma análise de U.Beck. In: VARELLA, Marcelo Dias (Org). Governo dos Riscos. Brasília: Editora Pallotti, 2005, p.9-40. 
O principal meio de participação são as audiências, e elas foram designadas pelo IBAMA quando o projeto já estava sendo objeto de ações judiciais, que objetivavam anular ou suspender atos (licenciamento; outorga; CERTOH; etc.). Muitas audiências foram marcadas de uma semana para outra, inviabilizando a análise do processo de licenciamento, em especial, do RIMA. Algumas delas foram agendadas para locais distantes da comunidade atingida.

Por várias vezes, as audiências foram suspensas, tanto por decisão judicial quanto por protestos populares. Alencar e Brasilino ${ }^{45}$, em matéria intitulada "Transposição revolta população" revelam que manifestações populares forçaram o IBAMA a cancelar a realização de audiências públicas. Assim sendo, esses instrumentos legais não serviram ao seu fim maior, qual seja, o de subsidiar a tomada de decisão; foram realizadas apenas para cumprirem os requisitos formais da legislação.

Não restam dúvidas: quando o projeto foi anunciado à sociedade, a decisão já estava tomada: ele seria executado independentemente da opinião popular e a do comitê. O projeto não foi modificado visando atender às expectativas sociais, ele sequer se coaduna com as diretrizes do Plano Decenal.

É nítida a vontade política de executar o projeto, indiferente da opinião popular, dos técnicos, da comunidade científica, etc. O Governo de Luís Inácio Lula da Silva alegava que "o projeto está de acordo com a lei" e assim o fez, inclusive no pertinente à participação popular, considerando que esta foi propiciada, nas audiências realizadas, pois a ata foi aberta e encerrada. Neste sentido, o Ministro Sepúlveda ${ }^{46}$, ao analisar a não realização das audiências, em virtude dos propostos populares, declarou que: "implicaria a punição do empreendedor, quando é certo que não se lhe pode imputar culpa pelos fatos". Sem dúvida, os protestos e os tumultos que impediram a realização das audiências mencionadas seriam motivações suficientes para o governo repensar sua decisão.

A real participação, isto é, aquela capaz de influenciar na decisão, pressupõe um debate, uma escolha conjunta sobre a decisão, portanto sobre a aceitabilidade ou não dos riscos ${ }^{47}$. A tomada de decisão deve agregar experts e leigos, porque se revela um processo de julgamento de valores que necessita, além do conhecimento científico qualificado, sobretudo, de legitimidade social. À medida que os riscos atingem grande parte da população, devem ser incorporados à decisão os interesses dessas pessoas. A aceitabilidade ou não dos riscos está diretamente ligada ao direito de participação dos cidadãos nas decisões que afetam suas vidas; caso contrário, ela simplesmente servirá para legitimar as decisões de um grupo dominante que detém o conhecimento ou a linguagem técnica em questão, sem o desconforto gerado pelos conflitos de opinião48.

Para Delnoy ${ }^{49}$, a participação popular efetiva pode: a) ser o remédio para as fraquezas estruturais ou conjunturais da democracia representativa permitindo ao cidadão recuperar uma parcela do poder e do controle; b) melhorar a qualidade das decisões em direção ao interesse coletivo; c) tornar mais eficaz as decisões administrativas, na medida em que a coletividade participa e dá apoio aos tomadores de decisão; d) reforçar a defesa dos direitos individuais; e) propiciar o cumprimento do dever de proteger o ambiente; f) favorecer a defesa dos interesses coletivos.

O licenciamento ambiental é um dos instrumentos da Política Nacional de Meio Ambiente (Lei 6.938/81, artigo $9^{\circ}$ inciso IV) para a gestão ambiental, devido aos instrumentos acautelatórios. Ele também se constitui a ferramenta principal de gestão dos riscos, visto que, no transcorrer do procedimento, podem ser impostas medidas preventivas, mitigatórias e compensatórias ou ser obstada a instalação de projetos, conforme os resultados das análises, caso seja o empreendimento ou a atividade de elevado potencial danoso ou de geração de riscos. Por meio do licenciamento, os princípios evocados podem ser postos em prática.

Ademais, o licenciamento tem, como escopo principal, conhecer o empreendimento e diagnosticar os problemas e as suas consequências de modo preliminar à instalação e ao

45 ALENCAR, Bernardo. BRASILINO, Luís. Transposição revolta população. Brasil de Fato, Belo Horizonte, p. 6, 10-16 fev. 2005.

46 BRASIL. Supremo Tribunal Federal. Ação Cível Originária 876. p. 46.

47 NARDOCCI, Adelaide Cássia. Gerenciamento Social de Riscos. Revista de Direito Sanitário, São Paulo, vol.3, n.1, p.75-76, mar. 2002.

48 NARDOCCI, Adelaide Cássia. Gerenciamento Social de Riscos. p.74.

49 DELNOY, Michel. Définition, notion de base, raison d'être et sources juridiques des procedures de participation du public. p.18-20. 
funcionamento, visando ao acautelamento de danos, riscos e impactos ao meio ambiente. Além do mais, objetiva prevenir a poluição, impedir a degradação ambiental e auxiliar na melhoria e na recuperação da qualidade ambiental.

Em decorrência do seu caráter acautelatório e do complexo conjunto de meios técnicos e científicos possíveis de serem empregados, além dos estudos específicos requisitados, como Estudo e Relatório de Impacto Ambiental (EIA/RIMA), Estudo e Relatório de Impacto de Vizinhança (EIV/ RIVI), Relatório de Controle Ambiental (RCA), entre outros, pode-se afirmar que o licenciamento ambiental é um instrumento eficiente para a gestão ambiental e dos riscos no Brasil. Todavia, por vezes, a práxis se afasta das normas positivadas e a finalidade da lei cede face aos interesses políticos, econômicos, individuais, entre outros.

Por sua vez, o licenciamento ambiental do Projeto da Transposição tornou-se emblemático, razão pela qual sua trajetória serve de reflexão para as futuras decisões. Esse licenciamento demonstra claramente a dificuldade de se cumprir a lei face aos interesses políticos, econômicos, financeiros, os quais, muitas vezes, predominam sobre os ambientais e sociais. Lamentavelmente, a normativização ambiental não induz à efetividade das normas.

\section{OS RISCOS DA TOMADA DE DECISÃO}

O EIA/RIMA da transposição realizado no licenciamento ambiental foi elaborado por equipe multidisciplinar, sob o encargo financeiro do Ministério da Integração e elenca 44 impactos ambientais decorrentes da execução do projeto, dos quais 23 foram considerados relevantes, sendo 12 negativos e 11 positivos (Tabela 01$)^{50}$. Embora o RIMA defina como "44 impactos", na verdade ele está apresentando 44 consequências. Necessário salientar que essas foram as apuradas pela equipe multidisciplinar.

Ressalta-se o fato de o EIA/RIMA não apresentar o diagnóstico completo dos impactos, dos danos e dos riscos decorrentes da transposição, tampouco fazer uma análise integrada e global, além de subdimensionar e desconsiderar consequências relevantes.

Dentre as 44 consequências, muitas extrapolam os níveis de tolerabilidade inerente à configuração técnico-jurídica de impacto ambiental, conforme a Resolução CONAMA 01/86 (artigo $1^{\circ}$ ). Assim, mais que impactos, algumas engendram riscos à coletividade, bem como configuram danos.

Experts que procederam à análise do RIMA afirmam que foram desconsideradas, por exemplo, aquelas decorrentes da cunha salina; da salinização de açudes; dos efeitos sobre o lençol freático; da geração de efluentes; da competição e dos conflitos entre os Estados da bacia doadora e da receptora; da viabilidade econômica da operacionalização do sistema, entre outros ${ }^{51}$.

Além do mais, foram subdimensionadas as decorrências referentes à redução da geração de energia $(-2,4 \%)$ e à perda de receitas municipais oriundas da compensação pelo uso dos potenciais hidrelétricos. Com tal execução, uma boa parte da água do rio São Francisco será direcionada aos canais e aos reservatórios da transposição, reduzindo a geração de energia elétrica e, com isso, as receitas da compensação. A queda na geração de energia elétrica poderá afetar a operacionalização do sistema da transposição e outras atividades industriais e urbanas na região. Tanto a redução de energia elétrica quanto a alteração na compensação financeira foram consideradas impactos irrelevantes.

Ainda cabe destacar que os Estados já se comprometeram com a cobrança de tarifa pelo uso da água e com a implantação da cobrança de tarifas pelos serviços de operação e manutenção do sistema operacional gerado pelas obras da transposição, pois a ANA condicionou a concessão do CERTOH à apresentação de garantias de gerenciamento futuro da obra ${ }^{52}$.

50 MINISTÉRIO DA INTEGRAÇÃO NACIONAL. Relatório de Impacto Ambiental da Transposição. p.75.

51 BAHIA, Carolina Medeiros. O Projeto da Integração do rio São Francisco às bacias do Nordeste Setentrional e a Lei 9433/1997. p. 20.

52 SALOMON, Marta. Obra do São Francisco consome 12 bilhões e ainda gera discussão. Nem greve de fome do bispo faz o governo cessar a liberação de recursos para o Projeto de Transposição. p. especial 03. 
O RIMA também subdimensionou os riscos e os danos ambientais, como extinção de espécies da fauna e da flora; a poluição das águas; a veiculação de vetores hídricos; a elevação de óbitos e enfermidades; as rupturas sociais causadas pelo deslocamento; o sobrecarregamento da infraestrutura urbana e o agravamento da qualidade dos serviços públicos prestados (saúde, moradia, educação, etc.).

Tabela 01: Os impactos da transposição do rio São Francisco

\begin{tabular}{|c|c|c|c|c|c|}
\hline & I MPACTOS & $\begin{array}{l}\text { FASE DE } \\
\text { PLAN" }\end{array}$ & $\begin{array}{l}\text { FASE DE } \\
\text { CONSTR. }\end{array}$ & $\begin{array}{l}\text { FASE DE } \\
\text { OPERACALAO }\end{array}$ & $\begin{array}{l}\text { NATUREZA } \\
\text { POSTIVOI } \\
\text { NECATINO }\end{array}$ \\
\hline 01 & Introdução de tensôes e riscos socials durante a construção & $\mathrm{x}$ & $x$ & & . \\
\hline 02 & Rupt ura de relaçóes sociocom un itárias durante a fase de obra & $\mathrm{x}$ & & & . \\
\hline 03 & Possıbılidade de Interferèncias corn populaçōes Indigenas & & $\mathrm{x}$ & $\mathrm{x}$ & . \\
\hline 04 & Risco de acidentes com a população & & $x$ & & . \\
\hline os & Aumento das emissóes de poeln & & $\mathrm{x}$ & $\mathrm{x}$ & $\cdot$ \\
\hline 06 & Aumento e/ou aparec imento de doenças & & $\mathrm{x}$ & $\mathrm{x}$ & . \\
\hline 07 & Aumento da demanda por Infra.estrutura de saúde & & $\mathrm{x}$ & & . \\
\hline 08 & Perda de terras potencialmente agricultávels & & $\mathrm{x}$ & & . \\
\hline 09 & Perda te mporária de empregos e renda por efe ito das desap rop riaçóes & & $\mathrm{x}$ & & . \\
\hline 10 & In terferènclas com áreas de processos m in erários & $\mathrm{x}$ & $\mathrm{x}$ & & . \\
\hline 11 & Cençâo de empregos e renda durante a implantaçâo & & $\mathrm{x}$ & & + \\
\hline 12 & Dinamização da economia regional & & $x$ & $\mathrm{x}$ & + \\
\hline 13 & Pressão sobre a infra-estrutura urbana & & $x$ & $\mathrm{x}$ & . \\
\hline 14 & $\begin{array}{l}\text { Especulaçâo imobillár la nas várzeas potenc lal mente } \\
\text { Irrigaivels no entorno dos canais }\end{array}$ & $\mathrm{x}$ & $\mathrm{x}$ & & . \\
\hline 15 & Risco de interferéncla corn o Patrimón lo Cultural & & $\mathrm{x}$ & $\mathrm{x}$ & . \\
\hline 16 & Aumento da oferta e da ganntia hidrica & & & $x$ & + \\
\hline 17 & Aumento da oferta de água para abastecimento urbano & & & $\mathrm{x}$ & + \\
\hline 18 & Abastecimento de água das populaçôes rura is & & & $\mathrm{x}$ & + \\
\hline 19 & Redução da exposição da populaçảo a situaçóes emergenclals de seca & & & $\mathrm{x}$ & + \\
\hline 20 & $\begin{array}{l}\text { Dinamização da atividade agrico la e incorporaçâo de novas áreas } \\
\text { a o processo produt lvo }\end{array}$ & & & $\mathrm{x}$ & + \\
\hline 21 & Diminulçâo do éxodo rural e da em Igraçâo da região & & & $\mathrm{x}$ & + \\
\hline 22 & Redução da exposição da população a doen ças e ób itos & & & $x$ & + \\
\hline 23 & Reduçâo da pressilo sobre a Infra-estrutura de saude & & & $\mathrm{x}$ & + \\
\hline 24 & $\begin{array}{l}\text { Perda e fragmentação de cerca de } 430 \text { hectares de áreas com vegetaçâo } \\
\text { nativa e de hábitats de fauna terrestre }\end{array}$ & & $\mathrm{x}$ & $\mathrm{x}$ & . \\
\hline 25 & Diminuição da divers ida de de fauna terrestre & & $\mathrm{x}$ & $\mathrm{x}$ & . \\
\hline 26 & $\begin{array}{l}\text { Aumento das at Ivida des de cạ̧a e dim inuiçâo das populaçôes } \\
\text { das espécles cinegéticas }\end{array}$ & & $\mathrm{x}$ & & . \\
\hline 27 & $\begin{array}{l}\text { Modificaçâo da compos ı̣̂a das Comun Ida des B ıológicas } \\
\text { Aquáticas Nativas das baclas receptoras }\end{array}$ & & & $\mathrm{x}$ & . \\
\hline 28 & $\begin{array}{l}\text { Risco de reduçâo da blodiversidade das Comunidades Biológicas } \\
\text { Aquáticas Nativas nas bacias receptoras }\end{array}$ & & & $\mathrm{x}$ & . \\
\hline 29 & $\begin{array}{l}\text { Comprometimento do conhecimento da histór la biogeográfica } \\
\text { dos grupos Biológicos Aquáticos Nativos }\end{array}$ & & & $\mathrm{x}$ & . \\
\hline 30 & $\begin{array}{l}\text { Risco de introduça de espécles de pelxes potenc blmente danin has ao } \\
\text { homem nas bacias receptoras }\end{array}$ & & & $\mathrm{x}$ & . \\
\hline 31 & Interferència sobre a pesca n os açudes receptores & & & $\mathrm{x}$ & . \\
\hline 32 & Risco de proliferaça de veto res & & & $\mathrm{x}$ & . \\
\hline 33 & Ocorréncia de acidentes com an Imais peçonhentos & & & $\mathrm{x}$ & . \\
\hline 34 & In stabillizaçâo de encostas marginais dos corpos d’água & & & $\mathrm{x}$ & . \\
\hline 35 & In íclo ou aceleraçáo de processos prosivos e carreamento de sediment os & & $\mathrm{x}$ & & . \\
\hline 36 & Modificação do regime fluvial das drenagens receptoras & & $x$ & $\mathrm{x}$ & . \\
\hline 37 & Alteração do comportam en to hidrossedi mentológico dos corpos d'água & & $x$ & $\mathrm{x}$ & . \\
\hline 38 & Rísco de eut rofizaçâo dos novos rese rvatór los & & $\mathrm{x}$ & $\mathrm{x}$ & . \\
\hline 39 & Melhoria da qualidade da água nas baclas receptoras & & & $\mathrm{x}$ & + \\
\hline 40 & Aumento da recarga fluvial dos aquifer os & & $\mathrm{x}$ & $\mathrm{x}$ & + \\
\hline 41 & In ic lo ou aceleraçâo dos processos de desertıficaçâo & & & $\mathbf{x}$ & . \\
\hline 42 & Modificação no regime fluvial do rio Sảo Francisco & & & $\mathrm{x}$ & . \\
\hline 43 & Reduçâo da geraçâo de en ergla e létrica no rio São Fran cisco & & & $\mathrm{x}$ & . \\
\hline 44 & Diminuiçâo de rece itas municipals & & & $\mathrm{x}$ & . \\
\hline
\end{tabular}


A propósito, o RIMA considera "impactos positivos relevantes" a geração de empregos e renda durante a implantação. Ao mesmo tempo, considera "impactos negativos relevantes" a perda temporária (no início das obras) de empregos e renda por efeito das desapropriações, assim como afirma que a busca frustrada de emprego nas obras irá gerar tensões e riscos sociais. Ratifica-se, não há um balanço global acerca da geração ou da perda de emprego decorrente da execução do projeto, entre outras ambiguidades ${ }^{53}$.

Outra importante falha do RIMA ${ }^{54}$ é ele "estranhamente" utilizar só o balanço hídrico da bacia receptora e não o de toda a bacia do São Francisco. O balanço total possibilitaria uma visão geral da demanda e da disponibilidade; portanto, dos resultados no âmbito da bacia, decorrentes do desvio de água.

Outro equívoco cometido pelo RIMA foi reduzir as análises dos "impactos" às áreas diretamente afetadas - ADA (faixa ao longo das estruturas do projeto com $5 \mathrm{~km}$ de largura para cada lado, totalizando $7.750 \mathrm{~km}^{2}$ ) às áreas de influência direta - AID (o conjunto de 86 municípios atravessados pelos eixos de condução da água, num total de $67.000 \mathrm{~km}^{2}$ ). Juntas, a ADA e AID somam menos de $75.000 \mathrm{~km}^{2}$; enquanto as desconsideradas, ou seja, as áreas de influência indireta (AII) somam um total de $787.000 \mathrm{~km}^{2}$, dos quais $212.453 \mathrm{~km}^{2}$ correspondem às bacias exclusivamente receptoras ${ }^{55}$. Nesse sentido, os estudos deveriam compreender a totalidade da bacia hidrográfica (correspondente a $8 \%$ do território nacional), mas desconsideraram todo o curso do Alto e Médio São Francisco.

Outro ponto importante: o projeto apresenta uma demanda média de $63,5 \mathrm{~m}^{3} / \mathrm{s}\left(24 \mathrm{~m}^{3} / \mathrm{s}\right.$ para o consumo humano, $14 \mathrm{~m}^{3} / \mathrm{s}$ para o industrial e $25,5 \mathrm{~m}^{3} / \mathrm{s}$ para a irrigação) e máxima de 127 $\mathrm{m}^{3} / \mathrm{s}$. Justifica-se por disponibilizar água para o consumo humano e industrial, mas disponibilizará mais água para a irrigação do que para o consumo humano. Assim, a afirmação de que ele visa beneficiar "as pessoas sedentas do Semiárido" é apelativa, porque o escopo principal do Eixo Norte é incrementar as atividades econômicas (indústria e agricultura) e garantir um superávit hídrico nos Estados do RN e CE. O deéficit hídrico nas regiões beneficiadas pelo Eixo Leste é reconhecido. No entanto isso não assegura que a água transposta por esse eixo estará à disposição dos habitantes, em restrição ao incremento dos usos econômicos.

Acrescenta-se ainda que a análise procedida pelo Centro de Estudos Ambientais da Bahia ${ }^{56}$ destaca que diversos estudos científicos revelam o estágio de sustentabilidade hídrica de alguns Estados, concebidos pelo projeto de integração como futuros beneficiários do empreendimento. Por exemplo, o Estado do Ceará apresenta a maior infraestrutura hídrica do Semiárido, acumulando em torno de 18,2 bilhões de $\mathrm{m}^{3}$, em aproximadamente, oito mil açudes públicos e privados.

O Centro de Recursos Ambientais da Bahia, no mesmo documento, afirma que, se fossem executadas algumas ações como as previstas na transposição, por exemplo, construção de canais, cisternas e bombeamento para ativação dessa disponibilidade (superficial, $54,2 \mathrm{~m}^{3} / \mathrm{s}$ e subterrânea, $16,3 \mathrm{~m}^{3} / \mathrm{s}$ ) - com recursos inferiores aos investidos na Transposição, - a própria bacia receptora $(\mathrm{CE}, \mathrm{RN}, \mathrm{PE}, \mathrm{PB})$ atenderia à demanda gerada pelo consumo.

Inúmeras ações judiciais foram propostas para cassar as licenças e serviram para demonstrar a irresignação da comunidade científica, de atores sociais, de membros dos Ministérios Públicos de diversos Estados e também do Federal e da população com os dados e as análises apresentados no EIA/RIMA.

O Banco Mundial fez uma análise acerca das alternativas à transposição e entende que outras medidas com efeitos de curto prazo deveriam ser primeiramente executadas (construção de cisternas e reservatórios para água da chuva; dessalinização da água, etc.), assim como projetos iniciados deveriam ser concluídos. O Relatório do Banco Mundial ${ }^{57}$ ressalta que o projeto terá baixo impacto na redução da pobreza e, igualmente, no alívio da seca:

53 HENKES, Silviana L. As decisões político-jurídicas frente à crise hídrica e aos riscos: lições e contradições da Transposição do Rio São Francisco. p.327-395.

54 MINISTÉRIO DA INTEGRAÇÃO NACIONAL. Relatório de Impacto Ambiental da Transposição. p. 02,50 .

55 MINISTÉRIO DA INTEGRAÇÃO NACIONAL. Relatório de Impacto Ambiental da Transposição. p. 54

56 CENTRO DE RECURSOS AMBIENTAIS DA BAHIA. Parecer Técnico 1028/2004. Salvador, 2004. p. 30. Disponível em: http://www.ana.gov.br/cbhsaofrancisco/index.htm. Acesso em: out. 2007.

57 BANCO MUNDIAL. Relatório sobre o Projeto de Transposição do rio São Francisco. p. 04,08-09. Disponível em: http:〈www.cbhsaofrancisco.org.br〉. Acesso em: out.2007. 
O projeto proposto só afetaria uma pequena porcentagem da população do Nordeste que sofre de periódica falta de água. Uma abordagem programática e estratégica mostra que esta população pode ser alcançada de forma mais efetiva através da combinação de atividades direcionadas.

Contudo, segundo o RIMA ${ }^{58}$, as alternativas ao projeto são: a) complementares em termos de público-alvo (construção de cisternas e poços); b) restritas em ocorrência espacial, quanto à qualidade da água e da distância (caso de água subterrânea e reúso do esgoto); c) limitadas em disponibilidade adicional (novos açudes); d) onerosas e tecnicamente menos eficientes.

Importa salientar que, apesar do elevado orçamento (de mais de $\mathrm{R} \$ 8$ bilhões), a água transposta não chegará diretamente à casa das pessoas. Muitos deles precisarão continuar a buscá-la em chafarizes públicos distantes de suas residências, em aproximadamente 400 localidades urbanas, todas inseridas somente na Área Diretamente Afetada. Essa obra beneficiará aproximadamente 70 mil pessoas e não 12 milhões de pessoas que habitam a região atingida pelo projeto ${ }^{59}$.

Desse modo, o problema da "falta de água" para a população local permanecerá, embora a disponibilidade hídrica local aumente, ou seja, a oferta de água crescerá, mas não resolverá todos os problemas (de acesso à água) da população. Novamente, evidencia-se que o grande problema consiste na democratização do acesso e não na oferta de água. Sob o mesmo prisma, Ab'Sáber60 enfatiza: "Nas discussões sobre a transposição das águas do São Francisco para o setor norte do Nordeste seco, existem alguns argumentos tão fantasiosos e mentirosos que merecem ser corrigidos". Segundo o autor, o primeiro deles é a transposição resolver os grandes problemas sociais da Região Semiárida: "Trata-se de um argumento completamente infeliz". A água transposta não vai solucionar o problema, se outras políticas não forem conjuntamente implementadas.

De acordo com o Centro de Recursos Ambientais da Bahia ${ }^{61}$ na análise dos impactos ambientais da Transposição, o RIMA selecionou apenas 11 unidades de conservação das 123 existentes na bacia receptora, por estarem na área de intervenção direta do empreendimento. Esse fato pode subdimensionar as consequências causadas à área integral. Cinco espécies exógenas à bacia do rio São Francisco, sob influência do empreendimento, já foram citadas como espécies com algum nível de risco de extinção: a pirapitinga (Brycon orthotaenia), a piabinha (Compsura heterura), a piabinha (Hemigrammus brevis), o mandi-açu (Duopalatinus emarginatus) e o niquim (Lophiosilurus alexandri).

A propósito, destaca-se que a área indiretamente afetada é uma área do patrimônio histórico e arquitetônico com construções dos séculos XVII e XVIII, além das riquezas naturais, como grutas, lagoas e reservas florestais e sítios arqueológicos de valor inestimável que serão atingidos e provavelmente destruídos pela transposição62.

Inúmeros outros questionamentos acerca da sustentabilidade da obra mostram-se pertinentes. Ab'Sáber ${ }^{63}$, em linhas gerais, destaca que pouco se pode adiantar, a não ser a falta de conhecimentos sobre a dinâmica climática e a periodicidade do rio que vai perder água e dos rios intermitentes e sazonários que vão receber filetes de águas transpostas.

Anunciada como a solução para a seca do Semiárido e a mola propulsora do desenvolvimento, a transposição já está gerando danos ambientais e sociais que não foram adequadamente contabilizados. Se houver desenvolvimento, com certeza não será sustentável.

\section{DO DESRESPEITO AO PLANO DECENAL E DA POLÍTICA NACIONAL DE RECURSOS} HÍDRICOS

O Plano Decenal da Bacia (2004-2013) restou, em boa medida, sem eficácia a partir da concessão das licenças ambientais e da decisão liminar concedida pelo STF. A primeira grande divergência

58 MINISTÉRIO DA INTEGRAÇÃO NACIONAL. Relatório de Impacto Ambiental da Transposição. p 33-35.

59 MINISTÉRIO DA INTEGRAÇÃO NACIONAL. Relatório de Impacto Ambiental da Transposição. p 09,82.

60 AB'SÁBER, Aziz Nacib. Sobre a Transposição do São Francisco. As águas do rio não são a panacéia para os problemas do Semi-Árido. p.98.

61 CENTRO DE RECURSOS AMBIENTAIS DA BAHIA. Parecer Técnico 1028/2004. p. 56.

62 CENTRO DE RECURSOS AMBIENTAIS DA BAHIA. Parecer Técnico 1028/2004. p. 40-59.

63 AB'SÁBER, Aziz Nacib. Sobre a Transposição do São Francisco. As águas do rio não são a panacéia para os problemas do Semi-Árido. p.98. 
surge da não observância dos termos da Deliberação do CBHSF 18 de 27/10/2004 que trata acerca das prioridades na concessão de outorga:

Art. $3^{\circ}$ - A concessão de outorga para uso externo à bacia hidrográfica do rio São Francisco fica restrita exclusivamente para consumo humano e dessedentação animal, atendidos os seguintes critérios: (sem grifo no original).

$[\ldots] ;$

III - clara comprovação de indisponibilidade hídrica local para atendimento da demanda apresentada e da inviabilidade econômica e/ou técnica de soluções nas bacias hidrográficas receptoras; (sem grifo no original).

De encontro à Deliberação do Comitê no. 18, a concessão da outorga hídrica definitiva pela Agência Nacional de Águas, em 22/09/2005, por meio da Resolução ANA 411, possibilita:

Art. $1^{\circ}$ - Outorgar ao Ministério da Integração Nacional o direito de uso de recursos hídricos do Rio São Francisco, para a execução do Projeto de Integração do São Francisco com as Bacias Hidrográficas do Nordeste Setentrional, nas seguintes condições:

IV - excepcionalmente, será permitida a captação da vazão máxima diária de $114 \mathrm{~m}^{3} / \mathrm{s}$ e instantânea de $127 \mathrm{~m}^{3} / \mathrm{s}$, quando o nível de água do Reservatório de Sobradinho estiver acima do menor valor entre:

a) nível correspondente ao armazenamento de $94 \%$ do volume útil; e

b) nível correspondente ao volume de espera para o controle de cheias;

Parágrafo único. Enquanto a demanda real for inferior a $26,4 \mathrm{~m}^{3} / \mathrm{s}$, o empreendimento poderá atender, com essa vazão, o uso múltiplo dos recursos hídricos na região receptora.

A Agência Nacional de Águas expediu em 22/09/2005, com publicação no Diário Oficial da União n० 185, em 26/09/2005, p. 89, o Certificado de Avaliação da Sustentabilidade da Obra Hídrica (CERTOH) para o Projeto de Integração do rio São Francisco. No dia seguinte ao da emissão da outorga, a ANA emitiu nota técnica declarando que "uma vazão média diária de $87,9 \mathrm{~m}^{3} / \mathrm{s}$ referente a outros usos da água pode ser bombeada eventualmente"64. A ANA, em nenhum momento, esclareceu o que é uma "situação excepcional" e quais seriam os "outros usos".

Assim, a utilização da água poderá beneficiar usos que não foram elencados como prioritários pelo Plano Decenal, contrariando-o, como também contrariando a Lei 9.433/97 (artigos 12 e13) e a Resolução CNRH 16/2001 (artigo $7^{\circ} \S 3^{\circ}$ ). Estes dispositivos legais determinam que toda outorga estará condicionada às prioridades de uso estabelecidas nos planos de recursos hídricos.

O Plano Decenal do CBHSF prescreve como usos prioritários: a) uso interno (dentro da bacia), em casos de escassez, para o consumo humano e a dessedentação de animais; b) uso para insumo produtivo restrito e exclusivo para usos internos da bacia. Além de estabelecer os usos prioritários e os demais elementos da gestão hídrica da bacia do rio São Francisco, o Plano Decenal estabelece que somente $360 \mathrm{~m}^{3} / \mathrm{s}$ podem ser alocados (outorgados), dos quais 335 já o foram. Sobram, então, $25 \mathrm{~m}^{3} / \mathrm{s}$ para utilização atual e futura de usos múltiplos, sendo prioritários os da bacia ${ }^{65}$.

O Projeto da Transposição infringe o Plano Decenal, pois requer, no mínimo, uma vazão continuada, de $26,4 \mathrm{~m}^{3} / \mathrm{s}$, a qual, por si, extrapola os limites reais da vazão outorgável prevista no plano em $1,4 \mathrm{~m}^{3} / \mathrm{s}$. Não obstante, conforme a outorga, o Certificado de Avaliação da Sustentabilidade da Obra Hídrica e a Nota Técnica expedida pela ANA podem conceder vazão maior: $65 \mathrm{~m}^{3} / \mathrm{s}, 87,9$ $\mathrm{m}^{3} / \mathrm{s}$ ou $127 \mathrm{~m}^{3} / \mathrm{s}$. A demanda da transposição supera a disponibilidade hídrica, acirrando-se ainda mais os conflitos hídricos na bacia.

Convém esclarecer que o Plano Decenal admite a concessão de água para usos externos (por exemplo, CE, RN, PB), todavia, visando ao consumo humano e à dessedentação animal, em caso de comprovada escassez e mediante clara comprovação da indisponibilidade hídrica local para o

64 LEITE, Marcelo. Política serve projetos de tempos em tempos. p. especial 04.

65 BAHIA, Carolina Medeiros. O Projeto da Integração do rio São Francisco às bacias do Nordeste

Setentrional e a Lei 9433/1997. p. 12. 
atendimento da demanda e da indisponibilidade econômica e/ou técnica de soluções nas bacias receptoras ${ }^{66}$.

No momento da outorga, o Comitê ainda não tinha estabelecido regras para a alocação espacial (por Estado) ou por tipo de uso consuntivo e, a partir da outorga, a negociação entre os Estadosmembros que compõem a bacia se torna mais complexa.

A Sociedade Brasileira para o Progresso da Ciência, no Relatório das Discussões sobre a Transposição, considera que o projeto se desvia dos fins propostos - fornecimento de água para o consumo humano e animal -, gerando preocupação quanto à partilha dos benefícios sociais do projeto67:

Há diferenças fundamentais quanto à justificação dos dois eixos propostos. O chamado Eixo Leste é proposto para o abastecimento humano das regiões mais secas de Pernambuco e da Paraíba e irrigação em sua maior parte na própria bacia do São Francisco. Por outro lado, o Eixo Norte, cujo objetivo é inequivocamente irrigação, baseia-se no princípio do aumento da sinergia dos grandes reservatórios do Ceará, Rio Grande do Norte e Paraíba.

Fontes ${ }^{68}$ declara que o Comitê solicitou à ANA a apresentação do balanço hídrico regional para constatar qual o real nível de escassez da bacia. Segundo o autor, apesar de a ANA prometer que entregaria o balanço durante o processo de análise da outorga e da emissão do Certificado de Avaliação da Sustentabilidade de Obra Hídrica, ele não foi entregue. Declara ainda o autor que a ANA concedeu a outorga somente com base nos dados fornecidos pelo Ministério da Integração Nacional, uma vez que o levantamento do balanço hídrico foi divulgado no Atlas do Nordeste Abastecimento Urbano de Água, após a concessão.

Pesquisadores da Sociedade Brasileira para o Progresso da Ciência, atores sociais e gestores hídricos afirmam que o Eixo Norte da Transposição tem como objetivo incrementar a produção agrícola e gerar um superávit hídrico, em especial no CE e no RN para uso em novos empreendimentos agrícolas e para a refinaria no Porto de Pecém (CE), objetivando o desenvolvimento econômico da região69.

A transposição potencializa ainda mais os conflitos já existentes, dificultando o desenvolvimento atual e futuro de diversas atividades relevantes para a bacia, principalmente geração de energia elétrica: o rio São Francisco representa mais de $90 \%$ de todo o potencial hidrelétrico inventariado no Nordeste (do Maranhão à Bahia). A irrigação, a navegação e a pesca também sofrerão seus efeitos, além de tornar ainda mais precário o consumo humano e a manutenção do ecossistema do rio São Francisco.

A propósito, o Plano Decenal destaca que os conflitos atuais podem ser acirrados em função de diversos fatores, dentre os quais: a) crescimento da agricultura irrigada na bacia; b) retirada de água da bacia por transposição; c) revitalização da navegação fluvial; d) aumento da demanda energética; e) demandas ecológicas e vazões remanescentes na foz ${ }^{70}$.

Desse modo, concedendo a outorga, a ANA não somente deixou de considerar aspectos técnicos relevantes, mas invalidou as decisões do Comitê; deixou de atender questões relacionadas à gestão da bacia, por exemplo, seus conflitos e a distribuição dos ônus sociais. Ao limitar-se à afirmativa de existir disponibilidade hídrica para a realização da obra, agravou ainda mais os conflitos regionais, principalmente entre Estados receptores e doadores, comprometendo usos presentes e futuros.

66 COMITÊ DA BACIA HIDROGRÁFICA DO RIO SÃO FRANCISCO. Plano Decenal de Recursos Hídricos da Bacia do rio São Francisco 2004-2013 (PBHSF) p. 147-148. Disponível em: <http://cbhsaofrancisco.org.br/>. Acesso em: 10. out. 2007.

67 SOCIEDADE BRASILEIRA PARA O PROGRESSO DA CIÊNCIA. Encontro Internacional sobre transferência de águas entre grandes bacias hidrográficas. Workshop sobre a Transposição de águas do rio São Francisco. Relatório das discussões. Recife, out. 2004. p.12-13. Disponível em: <http://www.risf. ana.gov.br>. Acesso em: 20/09/2006.

68 FONTES, Luis Carlos. Transposição: água para todos ou água para poucos? Anatomia da maior fraude hídrica e o conflito federativo de uso da água no Brasil. Revista do Comitê de Bacia Hidrográfica do rio São Francisco, Salvador, n.1. p.68. set.2007.

69 FONTES, Luis Carlos. Transposição: água para todos ou água para poucos? Anatomia da maior fraude hídrica e o conflito federativo de uso da água no Brasil. p.66-68.

70 COMITÊ DA BACIA HIDROGRÁFICA DO RIO SÃO FRANCISCO. Plano Decenal de Recursos Hídricos da Bacia do rio São Francisco 2004-2013. p. 11, 102-103, 123-124. 
Inviabilizou, igualmente, usos consuntivos de relevância para a região, em especial, a geração de energia elétrica e manutenção do ecossistema fluvial e costeiro associado à foz do rio. Sobretudo, apoderou-se da competência do Comitê atribuída pela PNRH, ao conceder a outorga (Lei 9.433/97, artigo $7^{\circ}$, inciso VIII c/c artigo 38, inciso III).

Em suma, a concessão da outorga para as obras da transposição infringe a Política Nacional de Recursos Hídricos, em especial no que diz respeito: a) ao Plano de Recursos Hídricos como o instrumento norteador da gestão hídrica na bacia, porquanto, apesar de sua existência e validade, ele não foi considerado pela ANA, MIN, MMA (artigo 60. e 70.); b) à concessão de outorga para a transposição, haja vista que a disponibilidade hídrica da bacia já está comprometida (artigo 11); c) ao desrespeito às prioridades de uso estabelecidas no Plano (artigo 13); d) à inobservância do papel do Comitê como gestor e articulador das questões relacionadas aos recursos hídricos no âmbito da bacia, pois invalidou as decisões tomadas pelo Comitê, sem a devida formalidade legal (artigo 38 e seu parágrafo único, dentre outros).

Além dessas irregularidades e infrações, outras podem ser observadas: a) o descumprimento do Decreto Federal no 4.024, o qual determina: as obras de infraestrutura hídrica da União devem obedecer a critérios de sustentabilidade operacional e hídrica, devidamente comprovados pela ANA;

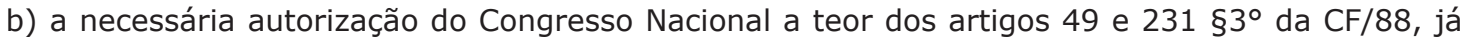
que as obras terão impacto em terras indígenas; c) a solicitação formal da anuência prévia dos gestores das unidades de conservação, conforme exigência da legislação específica não observada. Para o Professor Guimarães ${ }^{71}$, "uma auditoria isenta, com certeza, deveria revelar a inviabilidade do Projeto de Transposição e contestar a certificação da obra por parte da ANA".

A Sociedade Brasileira para o Progresso da Ciência ${ }^{72}$ adverte:

O projeto do Eixo Norte apresenta muitas incertezas no que se refere à viabilidade econômica e não há clareza quanto ao benefício social e à distribuição de renda que poderá ser gerada com o projeto. Além disso, em ambos os casos, a capacidade gerencial necessária para que as instituições públicas brasileiras venham a administrar o transporte de água em canais com centenas de quilômetros e a capacidade dos estados e da União de implementar as obras de modo a efetivamente utilizar a água, não condiz com o quadro atual, de dezenas de projetos inacabados e outros quase destruídos em função da má gestão. Portanto, seriam extremamente oportunas e prioritárias ações focadas na conclusão de inúmeras obras inacabadas existentes.

\section{CONSIDERAÇÕES FINAIS}

A realização da pesquisa comprovou a premissa teórica de Beck, bem como as duas hipóteses. As decisões, sejam administrativas ou judiciais, geram riscos.

Na pesquisa, constatou-se que a decisão do Conselho Nacional de Recursos Hídricos, ao aprovar a transposição; a decisão do IBAMA, ao conceder a licença ambiental prévia e também a licença de instalação; a decisão da Agência Nacional de Águas, ao conceder a outorga; a decisão do Governo Federal em executar o projeto; as decisões judiciais emanadas do Ministro Sepúlveda Pertence e a do Plenário do STF agregaram riscos, sem resolver boa parte dos problemas.

A segunda hipótese também ficou comprovada: a execução do Projeto de Transposição desconsidera preceitos do Direito Ambiental brasileiro, em especial os princípios da prevenção, da precaução e da participação pública, bem como inúmeros artigos da Política Nacional de Recursos Hídricos. As análises demonstraram que o licenciamento ambiental não foi eficiente como poderia, já que as práticas se distanciam do ideal normativo. Ademais, apesar de a tutela jurídica ter instrumentos hábeis, estes não têm impedido o aumento da degradação ambiental e a geração de riscos. Como se não bastasse, a participação popular está longe de ser efetiva.

Por sua vez, o RIMA não faz uma análise global e integrada das consequências da execução do projeto, porque ele aborda uma parte das consequências, subdimensionando-as, o que impossibilita a análise correta dos benefícios ou dos malefícios da transposição. A pesquisa, sedimentada em ampla

71 GUIMARÃES, João Abner Junior. O lobby da transposição. A Tarde, Salvador, p.01. 26 ago. 2004.

72 SOCIEDADE BRASILEIRA PARA O PROGRESSO DA CIÊNCIA. Encontro Internacional sobre transferência de águas entre grandes bacias hidrográficas. p.12-13. 
base de dados, documentos, estudos e depoimentos, constatou que a transposição gera benefícios econômicos (geração de empregos, aumento das terras irrigadas, etc.), mas outras alternativas poderiam ser mais eficazes e de menor impacto ambiental, social e financeiro.

Acerca do questionamento proposto, cumpre destacar também que a execução truncada do licenciamento e as falhas e as omissões relevantes no EIA/RIMA resultaram na proposição de inúmeras ações judiciais, visando interromper o licenciamento ambiental e a concessão das licenças ambientais. Assim, evidencia-se não apenas os riscos, bem como a inaceitabilidade social do projeto e do modo como foi conduzido.

Por derradeiro, cabe ainda salientar que o longo percurso judicial não findou, pois não há uma decisão transitada em julgado, mas o caminho até então percorrido é exemplificativo para se afirmar que: a) a decisão jurídica final (STF) ratificará as anteriores; b) a execução da obra, até o presente, já causou danos e impactos ambientais (negativos), além dos sociais de significativa repercussão e gravidade, além do descrédito na justiça brasileira por parte da população; c) os riscos ambientais impostos à coletividade decorrentes da execução da obra são de alta complexidade, comprometendo, inclusive, a própria operacionalização e manutenção do sistema. Ratifica-se, portanto, sua insustentabilidade, em que pese o RIMA ter elencado somente 44 consequências; d) os imbróglios jurídicos evidenciam o esvaziamento da função delegada aos comitês de bacia pela PNRH. Isso, por consequência, gera o descrédito na gestão hídrica participativa e nas instituições jurídicas vigentes; e) embora o Direito Ambiental brasileiro esteja munido de instrumentos aptos a promover o desenvolvimento sustentável, as práticas jurídicas têm demonstrado que o problema recai sobre a eficácia dos mesmos.

\section{REFERÊNCIAS}

AB'SÁBER, Aziz Nacib. Sobre a Transposição do São Francisco. As águas do rio não são a panacéia para os problemas do Semi-Árido. Scientific American Brasil, São Paulo, ano 3, n. 35, p.98, abr. 2005.

ALENCAR, Bernardo. BRASILINO, Luís. Transposição revolta população. Brasil de Fato, Belo Horizonte, p.6, 10-16 fev. 2005.

BAHIA, Carolina Medeiros. O Projeto da Integração do rio São Francisco às bacias do Nordeste Setentrional e a Lei 9433/1997. 2006, 22p. (datilografia).

BANCO MUNDIAL. Relatório sobre o Projeto de Transposição do rio São Francisco. 11p. Disponível em: http://www.cbhsaofrancisco.org.br. Acesso em: out.2007.

BECK, Ulrich. La sociedad del riesgo global. Madrid: Siglo Veintiuno de España Editores, 1999, 290p.

BECK, Ulrich. La sociedade del riesgo. Hacia uma nueva modernidad. Barcelona: Paidos, 1986, 304p.

BONI, Ana Paula. Governo quer levar água para 12 milhões de pessoas. Folha de São Paulo, São Paulo, p. especial 04, 09 out. 2005.

BRASIL. Supremo Tribunal Federal. Ação Cível Originária 876. Autores: Entidades Integrantes do Fórum de Defesa Permanente do São Francisco. Rés: União e IBAMA. Brasília. Relator Min. Sepúlveda Pertence. Brasília 18 dez. 2006. Disponível em: http://www.stf.gov.br. Acesso em: out.2007.

CAUBET, Christian Guy; ARAÚJO, José Theodomiro de. Le transfert des eaux du fleuve. São Francisco. Écologie \& Politique, n. 29, p. 153-169, 2004.

CENTRO DE RECURSOS AMBIENTAIS DA BAHIA. Parecer Técnico 1028/2004. Salvador, 2004. 100p. Disponível em: 〈http://www.ana.gov.br/cbhsaofrancisco/index.htm〉. Acesso em: out. 2007.

COELHO, Marco Antônio Tavares. A transamazônica de Lula. Correio Braziliense, Brasília, 27 set. 2004. Disponível em: 〈http://www.risf.ana.gov.br〉. Acesso em: 10 set. 2006.

COMITÊ DA BACIA HIDROGRÁFICA DO RIO SÃO FRANCISCO. Plano Decenal de Recursos Hídricos da Bacia do rio São Francisco 2004-2013 (PBHSF) 337p. Disponível em: http://cbhsaofrancisco.org. br. Acesso em: out. 2007. 
COMITÊ DA BACIA HIDROGRÁFICA DO RIO SÃO FRANCISCO. Plano Decenal de Recursos Hídricos da Bacia do rio São Francisco 2004-2013 (PBHSF) 337p. Disponível em: < http://cbhsaofrancisco.org. br/>. Acesso em: 10. out. 2007.

DELNOY, Michel. Définition, notion de base, raison d'être et sources juridiques des procedures de participation du public. In: JADOT, Benoît. La participation du public au processus de decision en matière d'environnement et d'urbanisme. Bruxelles: Bruylant, 2005, p.07-28.

FONTES, Luis Carlos. Transposição: água para todos ou água para poucos? Anatomia da maior fraude hídrica e o conflito federativo de uso da água no Brasil. Revista do Comitê de Bacia Hidrográfica do rio São Francisco, Salvador, n.1. p.60-73, set.2007.

GUIMARÃES, João Abner Junior. O lobby da transposição. A Tarde, Salvador, 26 ago. 2004. Disponível em http://www. risf.ana.gov.br. Acesso em: 10 out. 2005.

HENKES, Silviana L. As decisões político-jurídicas frente à crise hídrica e aos riscos: lições e contradições da Transposição do Rio São Francisco. Tese (Doutorado em Direito). Curso de Pós-Graduação em Direito. Universidade Federal de Santa Catarina. Florianópolis. 2008.

LEITE, Marcelo. Política serve projetos de tempos em tempos. Folha de São Paulo, São Paulo, p. especial 07,09 out. 2005 .

MARCONDES, Neusa; ANDRADE, Marília Freire de. A História se repete. Como Trajédia ou como comédia. In: DOWBOR, Ladislau; TAGNIN, Rentato Arnaldo (Orgs). Administrando a água como se fosse importante. Gestão Ambiental e sustentabilidade. São Paulo: Senac, 2005, p.73-79

MINISTÉRIO DA INTEGRAÇÃO NACIONAL. Site oficial do Ministério da Integração Nacional. Contém informações, projetos e ações executadas. Disponível em: <http://www.integracao.gov.br>. Acesso em: jan-dez. 2007 e janeiro-março 2013.

MINISTÉRIO DA INTEGRAÇÃO NACIONAL. Relatório de Impacto Ambiental da Transposição, Brasília, jul. 2004 136p.

MINISTÉRIO PÚBLICO FEDERAL. Site oficial do Ministério Público Federal. Contém informações, projetos e ações executadas. Disponível em: <http://www.mpf.gov.brr>. Acesso em: jan-dez. 2007, março 2008 e janeiro-março 2013.

NARDOCCI, Adelaide Cássia. Gerenciamento Social de Riscos. Revista de Direito Sanitário, São Paulo, vol.3, n.1, p.64-78, mar. 2002.

POMPEU, Carolina. Suspensa a Transposição do São Francisco. Notícias do Ministério Público Federal. Disponível em: http:// noticias.pgr.mpf.gov.br/noticias-dosite. Acesso em: 11 dez.2007.

SALOMON, Marta. Obra do São Francisco consome 12 bilhões e ainda gera discussão. Nem greve de fome do bispo faz o governo cessar a liberação de recursos para o Projeto de Transposição. Folha de São Paulo, São Paulo, p. especial 03, 09 out.2005.

SOCIEDADE BRASILEIRA PARA O PROGRESSO DA CIÊNCIA. Encontro Internacional sobre transferência de águas entre grandes baicas hidrográficas. Workshop sobre a Transposição de águas do rio São Francisco. Relatório das discussões. Recife, out. 2004. p.12-13. Disponível em:〈http://www.risf.ana. gov.br〉. Acesso em: 20/09/2006.

TRIBUNAL DE CONTAS DA UNIÃO. Acórdão 2017/2006, de 03 nov.2006, publicado no D.0.U. 06 nov. 2006. Disponível em: http://www.cbhsao_francisco.org.br. Acesso em: nov. 2006.

VILLA, Marco Antônio. Um projeto de quase 2 séculos. Estado de São Paulo, São Paulo, 04 fev.2004. Disponível em: http:// www.ana.gov.br. Acesso em: out.2007. 